\section{Policy impacts on the EU-Russian trade performance: The case of agri-food trade}

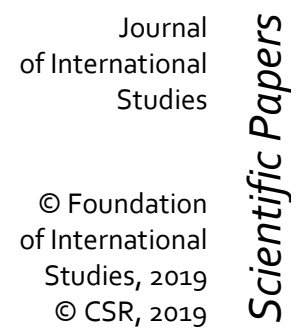

\author{
Luboš Smutka \\ Faculty of Economics and Management, \\ Czech University of Life Sciences Prague, \\ Crech Republic \\ smutka@pef.czu.cz.
}

Mansoor Maitah

Faculty of Economics and Management, Czech University of Life Sciences Prague, Crech Republic

maitab@pef.czu.cz.

\author{
Miroslav Svatoš \\ Faculty of Economics and Management, \\ Czech University of Life Sciences Prague, \\ Czech Republic \\ svatos@pef.cru.cr.
}

Abstract: The main goal of this paper is to provide an overview of the impact from Russian import ban on trade between the Russian Federation and the selected Western countries - especially EU members. Because of the applied ban characteristics, the European Union could be considered as the most affected subject of Russian protectionism. This paper identifies the changes affecting EU agrarian export performance in relation to the Russian Federation. Changes in the trade of vegetables, fruits, meat and animal products, dairy and dairy products and fish are identified. This paper also $8330.2019 / 12-2 / 5$ provides an overview of changes related to Russian trade competitiveness and territorial structure. The result of the applied import ban was a significant reduction of Russian agrarian import value - within the first three years alone, the value of imports was reduced by 7,389 million USD. The import ban also changed the overall competitiveness of Russian agricultural trade, while recognising that the comparative advantages of some commodity groups was reduced. The processed data is analysed through a set of the following instruments: self-sufficiency ratio, import dependency ratio and in the final part of the paper, the Lafay index (LFI) will be used for a brief analysis of the comparative advantages of the products included in the ban. 
Keywords: import ban, commodity structure, territorial structure, western countries, European Union.

\section{JEL Classification: Q1}

\section{INTRODUCTION}

In 2013 to 2014, Russian-Ukrainian political confrontation resulted in an increasing tension between the Russian Federation and many Western countries. Because of Russia's aggressive policy, the USA, the EU-28, Canada, Norway, Australia and some other countries applied economic sanctions against Russia. In response to these sanctions, the Russian Federation decided to apply some retaliatory measures. Decree No. 560 may be one of the most significant responses to the applied sanctions in history. On August 6, 2014, President Putin issued the Decree "On Special Economic Measures to Protect Russia's Security". The result was an import ban applied to agricultural and foodstuff imports from Australia, Canada, Norway, the USA and the EU. In the beginning, this ban was intended for one year only; however, it was later decided that it should be extended.

Russian food import ban needs to be understood not only in the political context of retaliation for the applied sanctions and criticism from Western countries. This ban is also the result of long-run Russian food security and food independence policy (Kastakova, 2012). During the period of Russian economic transformations, the agricultural sector nearly collapsed. Russian food self-sufficiency was significantly reduced. In the period from 1991 to 2005, the volume and the value of national food production had decreased, while the value and the volume of food imports were consistently increasing. Such a development consistently increased the negative Agri-Food Trade balance (Svatos et al., 2014). The transformation period also negatively affected Russian agrarian trade commodity and territorial structure. This was particularly evident in the export commodity structure, as it became more concentrated, bulk commodities especially. On the other hand, the import profile became very heterogeneous and because of low import prices, it represented a significant barrier for Russian agricultural sector recovery (Ishchukova \& Smutka, 2014). In the period before the import ban was applied, Russian government had been seeking reasons to protect its market and thus increase national food security (Erokhin et al., 2014). Sanctions from Western countries gave Russian government an excuse to apply its plans for supporting the expansion of the domestic agricultural sector. Foreign competitors were driven out of the Russian market and Russian consumers had to accept the increase in local food prices. Subsequently, reduced competition and higher consumer prices have encouraged Russian food producers increase their production performance.

The applied import ban supported the original Russian government's Doctrine of Food Security (grain - 95\% self- sufficiency, sugar - 80\% self-sufficiency, vegetable oil - $80 \%$ self--sufficiency, meat and meat products $-85 \%$ self-sufficiency, milk and dairy products $-90 \%$ self-sufficiency, fish products $-80 \%$ self-sufficiency, potatoes - 95\% self-sufficiency, edible salt - 85\% self-sufficiency) (Doctrine of Food Security of RF, 2009). The applied ban affected the imports of vegetables, fruits, animal and dairy products, and fish and fish products.

Russian agrarian import ban has been extended and changed several times since 2014: On May 27, 2016, the Russian Government issued Decree No. 472; On October 22, 2016, the Russian Government issued Decree No. 1086; On October 25, 2017, the Government of Russia issued Decree No. 1292. 


\section{LITERATURE REVIEW}

The main goal of this paper is to identify the fundamental changes in EU-Russian mutual agricultural trade performance in the period after the Russian import ban was applied in relation to selected countries, particularly EU members. The paper has identified the primary changes in commodity and territorial structure performance. Another important goal is to identify changes in EU Agri-Food Trade comparative advantages distribution in relation to Russia as the applied ban changed characteristics of EU exports.

The processed paper is closely related to an already published paper entitled "Agrarian import ban and its impact on the Russian and European Union agrarian trade performance" (Smutka et al., 2016). While this paper reviewed the data concerning EU-Russian trade in the period of 2000-2013 and preliminary data for 2014, our paper provides a clear overview of the real import ban impact on Russian trade with affected countries. While the first article was devoted to estimations of possible impacts, this paper provides a clear overview of the changes in territorial and commodity structure related to Russian imports influenced by the applied food import ban (analysis is summarizing the impact of sanctions in period 2014-2016).

This paper is focused on providing an overview of the applied Russian import ban impact on the first set of countries (Australia, Canada, European Union, Norway, and the United States of America). Those countries' agricultural trade has been affected by the Russian import ban over the last five years (20142018) and it is expected that the import ban will be enforced until at least 2019. During the last few years, the list of countries and items included in the ban has increased. However, because of data availability, this paper has analysed the impact of the applied ban on original countries and changes in their agricultural trade performance. In addition, Russian territorial structure is analysed for the period 2014-2016.

\section{METHODOLOGY}

The primary sources of data for the analysis are the Federal Customs Service of Russia and the UN Comtrade. The data utilized in the analyses is organized according to the Harmonized Commodity Description and Coding System (HS) of the World Customs Organisation.

The most affected commodity aggregations are the following: meat and meat products, milk and dairy products, vegetable and fruit and fish. The specific list of commodities affected by applied ban is published by Russian Government authorities (GSPI, 2018) or it is available published also by USDA (2017).

The processed data is analysed through a set of the following instruments (for the possibility to compare the real impact of the import ban - the same methodology is used in the paper Smutka et al., 2016 is applied):

\subsection{Self-sufficiency ratio (SSR)}

The level of self-reliance for certain types of agricultural products is determined by the percentage of agricultural production to the consumption of the country.

Self-sufficiency in agricultural products reflects the extent to which domestic production in the country is able to meet the domestic consumption of the country or its regions.

In general, the algorithm for calculating the food self-sufficiency ratio can be expressed utilizing the following formula:

$$
S S R=\frac{\text { Production }}{\text { Amounts of Domestic Supply }}
$$




\subsection{Import dependency ratio (IDR)}

In the course of the analysis of the food situation of a country, an important aspect to identify is how much of the available domestic food supply has been imported, and how much comes from the country's own production.

$$
I D R=\frac{\text { Imports }}{\text { Amounts of Domestic Supply }}
$$

In the final part of the paper, the Lafay index (LFI) will be used for a brief analysis of the comparative advantage of products included in the ban. The index considers the difference between each item of the normalised trade balance and the overall normalised trade balance.

For a given country $i$, and for any given product $j$, the Lafay index is defined as:

$$
L F I_{j}^{i}=100\left(\frac{x_{j}^{i}-m_{j}^{i}}{x_{j}^{i}+m_{j}^{i}}-\frac{\sum_{j=1}^{N}\left(x_{j}^{i}-m_{j}^{i}\right)}{\sum_{j=1}^{N} x_{j}^{i}+m_{j}^{i}}\right) \frac{x_{j}^{i}+m_{j}^{i}}{\sum_{l=1}^{N} x_{j}^{i}+m_{j}^{i}}
$$

Where $x_{j}^{i}$ and $m_{j}^{i}$ represent exports and imports of product $j$ of country $i$, towards and from a particular region or the rest of the world, respectively, and $\mathrm{N}$ is the number of items. Positive values of the Lafay index indicate the existence of comparative advantages in a given item; the larger the value, the higher the degree of specialisation (Zaghini, 2003). The LFI value was calculated for the years of 2013 and 2016 at the level of individual items (HS 2 digit code) representing mutual trade performance between EU and the Russian Federation. The total Agri-Food Trade performance is considered as the base for the individual Agri-Food items trade comparative advantages calculation.

\section{EMPIRICAL RESULTS AND DISCUSSION}

Russian agricultural policy is interested in the growth of food self-sufficiency and independence. The Russian government implemented legislation and set up an ambitious plan to encourage increased national agricultural production performance. As it was already mentioned, some experts for Russian agriculture, trade and policy are convinced that the applied import ban is one of several instruments applied to support national production capacities and to increase national food self-sufficiency. The applied ban significantly changed the territorial as well as the commodity structure of Russian agricultural trade (especially the structure of imports).

If our interest is to get a better overview about the real impact of the applied agricultural import ban in relation to several Western countries, it is necessary to understand some basic aspects related to the role of agriculture within Russian society and the economy. First, agriculture represents a significant pillar for Russian rural area development. Nearly $25 \%$ of the Russian population is living in rural areas, and nearly $7 \%$ of the economically active population are working in the agriculture sphere. The agricultural population represents about $10-15 \%$ of the total population. Agriculture is also extremely important for the development of local infrastructure and some other externalities.

As it is demonstrated above, The Russian Federation has suffered from a significant level of import dependency, especially in the case of vegetables, fruits, meat and dairy products, and fish and crustaceans. The applied import ban is not a random one. The ban is applied exactly in relation to those commodity 
items representing the weakness of the Russian agriculture and foodstuff markets. The potential to increase production capacity and performance is significant. The only problem of increasing selfsufficiency and production performance is competitiveness and limited cost efficiency. The applied ban provides the possibility to develop local production capacities and performance. There are two side effects related to the applied ban. The first effect is a political one; increasing food independence and the support of national production capacities. The second one is related to economic issues - a reduction of consumers, increasing food prices and reduction of the agrarian trade deficit. When focusing specifically on trade performance, the Russian government is interested in changing the existing imbalance between agrarian imports $(12.5 \%$ of total imports) and exports (5\% of total exports) in relation to total merchandise trade performance.

Production, consumption and import dependency of the Russian Federation

Table 1

For basic agricultural products, thousand tonnes

\begin{tabular}{|c|c|c|c|c|c|c|c|c|c|c|c|c|}
\hline & \multicolumn{4}{|c|}{ Grain } & \multicolumn{4}{|c|}{ Vegetables } & \multicolumn{4}{|c|}{ Fruits and berries } \\
\hline & 2000 & 2010 & 2013 & 2016 & 2000 & 2010 & 2013 & 2016 & 2000 & 2010 & 2013 & 2016 \\
\hline Production & 65.4 & 61.0 & 92.4 & 120.7 & 11,359 & 13,278 & 16,109 & 18,041 & 2,969 & 2,474 & 3,380 & 3,863 \\
\hline Private consumption & 0.1 & 0.1 & 0.1 & 0.1 & 11,476 & 14,426 & 15,712 & 16,358 & 4,659 & 8,242 & 9,180 & 9,021 \\
\hline Industrial consumption & 62.9 & 64.3 & 64.5 & 74.1 & 1,403 & 1,662 & 1,996 & 2,128 & 612 & 728 & 975 & 1,097 \\
\hline Consumption per capita, kg* & 117 & 120 & 118 & 139 & 79 & 101 & 109 & 114 & 32 & 58 & 64 & 63 \\
\hline Import & 4.7 & 0.4 & 1.5 & 1.0 & 2,273 & 3,158 & 2,817 & 2,321 & 2,640 & 6,780 & 7,201 & 6,517 \\
\hline Export & 1.3 & 13.9 & 19.0 & 33.9 & 169 & 543 & 658 & 1,217 & 47 & 56 & 139 & 169 \\
\hline Self-sufficiency ratio & $103 \%$ & $93 \%$ & $140 \%$ & $160 \%$ & $86 \%$ & $80 \%$ & $88 \%$ & $87.5 \%$ & $56 \%$ & $27 \%$ & $33 \%$ & $37 \%$ \\
\hline Import dependency ratio & $7 \%$ & $1 \%$ & $2 \%$ & $0.83 \%$ & $17 \%$ & $19 \%$ & $15 \%$ & $12 \%$ & $50 \%$ & $75 \%$ & $70 \%$ & $63 \%$ \\
\hline \multirow[t]{3}{*}{ Import to Export ratio } & 3.6 & 0.03 & 0.08 & 0.03 & 13 & 6 & 4 & 1.9 & 56 & 121 & 52 & 38 \\
\hline & \multicolumn{4}{|c|}{ Meat and meat products } & \multicolumn{4}{|c|}{ Milk and milk products } & \multicolumn{4}{|c|}{$\begin{array}{c}\text { Fish and crustaceans, } \\
\text { (thousand tonnes) }\end{array}$} \\
\hline & 2000 & 2010 & 2013 & 2016 & 2000 & 2010 & 2013 & 2016 & 2000 & 2010 & 2013 & 2016 \\
\hline Production & 4,446 & 7,167 & 8,545 & 9,899 & 32,259 & 31,847 & 30,529 & 30,759 & 4,047 & 4,179 & 4,296 & 4,812 \\
\hline Private consumption & 6,564 & 9,871 & 10,812 & 10,851 & 31,317 & 35,237 & 35,633 & 34,666 & 2,619 & 3,207 & 2,800 & 2,854 \\
\hline Industrial consumption & 57 & 37 & 51 & 49 & 5,205 & 4,271 & 3,742 & 3,163 & 849 & 456 & 414 & 526 \\
\hline Consumption per capita, kg & 45 & 69 & 75 & 76 & 213 & 248 & 249 & 241 & 17.9 & 21.2 & 22.0 & 23.5 \\
\hline Import & 2,095 & 2,855 & 2,480 & 1,246 & 4,718 & 8,159 & 9,445 & 7,544 & 922 & 1,504 & 884 & 1,055 \\
\hline Export & 35 & 97 & 117 & 236 & 507 & 460 & 628 & 645 & 1,513 & 2,019 & 1,509 & 2,234 \\
\hline Self-sufficiency ratio & $67 \%$ & $72 \%$ & $79 \%$ & $91 \%$ & $88 \%$ & $81 \%$ & $77 \%$ & $81 \%$ & $154 \%$ & $130 \%$ & $133 \%$ & $142 \%$ \\
\hline Import dependency ratio & $32 \%$ & $29 \%$ & $23 \%$ & $11 \%$ & $13 \%$ & $21 \%$ & $24 \%$ & $19 \%$ & $26 \%$ & $41 \%$ & $24 \%$ & $19 \%$ \\
\hline Import to Export ratio & 60 & 29 & 21 & 5.28 & 9 & 18 & 15 & 11.6 & 0.6 & 0.7 & 0.6 & 0.47 \\
\hline
\end{tabular}

The grain table represents the consumption of bread, bakery products and cereals per capita.

Source: Russian Federal State Statistics Service (2017), Faostat database (2017)

The purpose of the following analysis is to identify the impact/efficiency of the applied ban on Russian agrarian trade in relation to countries affected by the applied ban. The following tables provide an opportunity to evaluate changes in trade performance between Russia and the countries that were affected by the ban between 2013 (just one year before the ban was applied) and 2016 (third year of applied ban). 
In 2016, the total value of Russian food imports decreased by $42 \%$ in relation to 2013 . The value of imports of products subject to the ban decreased during the analysed period by $57 \%$.

The impact was clearly felt in the first year of the applied ban, as mutual trade between the Russian Federation and banned countries were definitely affected. If we compare Russian import value of banned products in 2013 (9,007 million USD) to the value performance one year later (2014), it is possible to see a sizable reduction of 3,888 million USD (but ban was applied only for last five months). One year later (2015), the applied ban had already caused the reduction of imports of banned products by another 4,247 million USD (in comparison to previous year).

Table 2

The value of Russian imports of banned products in 2013 (before ban) - 2016 (after the ban had been applied 2014-2016), million USD

\begin{tabular}{|c|c|c|c|c|c|}
\hline & 2013 & 2014 & 2015 & 2016 & 2016 to 2013 \\
\hline Total agricultural products: & \multirow{2}{*}{43,164} & \multirow{2}{*}{39,715} & \multirow{2}{*}{26,651} & \multirow{2}{*}{25,031} & \multirow{2}{*}{$-18,133$} \\
\hline - from all countries & & & & & \\
\hline - from countries under sanctions & 18,881 & 14,429 & 6,491 & 6,283 & $-12,598$ \\
\hline \multicolumn{6}{|l|}{ Banned products from: } \\
\hline - all countries & 23,135 & 20,31 & 11,287 & 10,035 & $-13,100$ \\
\hline - countries under sanctions & 9,007 & 5,119 & 872.508 & 742.337 & $-8,264$ \\
\hline \multicolumn{6}{|l|}{ Including } \\
\hline$E U$ & 6525 & 3481 & 812.908 & 683.402 & $-5841,598$ \\
\hline AUSTRALIA & 182 & 103 & 0.351 & 0.004 & $-181,996$ \\
\hline CANADA & 373 & 394 & 0.831 & 0.387 & $-372,613$ \\
\hline NORWAY & 1146 & 582 & 0.757 & 0.147 & $-1145,853$ \\
\hline UNITED STATES & 781 & 559 & 57.661 & 58.397 & $-722,603$ \\
\hline
\end{tabular}

Source: Federal Customs Service of Russia (2016), UN Comtrade 2017

In 2016, imports of banned products from the affected countries barely reached 742 million USD. That means that the applied ban reduced mutual trade between Russia on one side and EU, Australia, Canada, Norway, USA on the opposite side by nearly $92 \%$ (for more details see Tables $2,3,4,5$ ).

Table 3

Product groups affected by import ban in 2013

\begin{tabular}{|c|c|c|c|c|c|c|c|c|c|c|c|c|}
\hline & \multicolumn{2}{|c|}{$\mathrm{EU}$} & \multicolumn{2}{|c|}{ Australia } & \multicolumn{2}{|c|}{ Canada } & \multicolumn{2}{|c|}{ Norway } & \multicolumn{2}{|c|}{ USA } & \multicolumn{2}{|c|}{ Total } \\
\hline & $\begin{array}{c}\text { million } \\
\text { USD }\end{array}$ & $\%$ & $\begin{array}{l}\text { million } \\
\text { USD }\end{array}$ & $\%$ & $\begin{array}{c}\text { million } \\
\text { USD }\end{array}$ & $\%$ & $\begin{array}{c}\text { million } \\
\text { USD }\end{array}$ & $\%$ & $\begin{array}{c}\text { million } \\
\text { USD }\end{array}$ & $\%$ & $\begin{array}{c}\text { million } \\
\text { USD }\end{array}$ & $\%$ \\
\hline $02-$ Meat & 1,548 & $24 \%$ & 130 & $72 \%$ & 247 & $66 \%$ & 0 & $0 \%$ & 357 & $46 \%$ & 2,282 & $25 \%$ \\
\hline 03 - Fish & 216 & $3 \%$ & 1 & $1 \%$ & 119 & $32 \%$ & 1,142 & $100 \%$ & 76 & $10 \%$ & 1,554 & $17 \%$ \\
\hline $04-$ Milk & 1,738 & $27 \%$ & 44 & $24 \%$ & 0 & $0 \%$ & 4 & $0 \%$ & 0 & $0 \%$ & 1,787 & $20 \%$ \\
\hline 07 - Vegetables & 935 & $14 \%$ & 0 & $0 \%$ & 3 & $1 \%$ & 0 & $0 \%$ & 8 & $1 \%$ & 946 & $11 \%$ \\
\hline $08-$ Fruits & 1,519 & $23 \%$ & 7 & $4 \%$ & 2 & $1 \%$ & 0 & $0 \%$ & 231 & $30 \%$ & 1,759 & $20 \%$ \\
\hline $\begin{array}{l}\text { 16, 19, } 21 \text { - Food } \\
\text { prep. }\end{array}$ & 568 & $9 \%$ & 0 & $0 \%$ & 2 & $1 \%$ & 0 & $0 \%$ & 108 & $14 \%$ & 679 & $8 \%$ \\
\hline Total & 6,525 & $100 \%$ & 182 & $\begin{array}{l}100 \\
\%\end{array}$ & 373 & $\begin{array}{c}100 \\
\%\end{array}$ & 1146 & $100 \%$ & 781 & $100 \%$ & 9,007 & $\begin{array}{c}100 \\
\%\end{array}$ \\
\hline
\end{tabular}

Source: Federal Customs Service of Russia (2015)

As a consequence of the sanctions being applied, the share of the banned countries' food products as a share of the total Russian food imports steadily declined. In the period of 2014 to 2016, their share 
reduced from cc $44 \%$ to cc $25 \%$. The most affected subject of applied sanctions was the European Union. In the period before the sanctions, the EU's share of Russian imports of subsequently banned food products was nearly 15\%, while in 2016 it was only $2.73 \%$ (for details see Table 4) (exports to Russia reduced by 5.8 billion USD). Sanctions also significantly affected countries such as Norway (exports to Russia reduced by 1.1 billion USD). Table 5 provides an overview of the trade exports of product groups affected by the Russian import ban at the level of individually affected countries. If we compare the situation in 2013 (Table 3) to that in 2016, it is clear to that there were decreases across the board. These decreases are highlighted below.

The value of meat exports was reduced from 2.282 billion USD to 536 million USD, the value of fish exports was reduced from 1.55 billion USD to 64 million USD, the value of milk and milk product exports was reduced from 1.78 billion USD to 4.3 million USD, the value of vegetable exports was reduced from 946 million USD to 59 million USD, the value of fruit exports was reduced from 1.76 billion USD to 70 million USD, and the value of food preparations exported was reduced from 679 million USD to 487 million USD. Based on the data presented below, the countries of the European Union can be considered as the primary loser of the applied Russian import ban policy.

Table 4

The share of banned products in the Russian agricultural import market from 2013-2016

\begin{tabular}{|l|c|c|c|c|}
\hline & 2013 & 2014 & 2015 & 2016 \\
\hline Total agricultural products: & $100 \%$ & $100 \%$ & $100 \%$ & $100 \%$ \\
\hline - from all countries & & & & $25,10 \%$ \\
\hline - from countries under sanctions & $43,74 \%$ & $36,33 \%$ & $24,36 \%$ & \\
\hline Banned products from: & & & & $40,09 \%$ \\
\hline - all countries & $53,60 \%$ & $51,14 \%$ & $42,35 \%$ & $2,97 \%$ \\
\hline - countries under sanctions & $20,87 \%$ & $12,89 \%$ & $3,27 \%$ & $2,73 \%$ \\
\hline Including & & & & $0,00 \%$ \\
\hline EU & $15,12 \%$ & $8,76 \%$ & $3,05 \%$ & $0,00 \%$ \\
\hline CANTRALIA & $0,42 \%$ & $0,26 \%$ & $0,00 \%$ & $0,00 \%$ \\
\hline NORWAY & $0,86 \%$ & $0,99 \%$ & $0,00 \%$ & $0,23 \%$ \\
\hline UNITED STATES & $2,65 \%$ & $1,47 \%$ & $0,00 \%$ & $0,22 \%$ \\
\hline
\end{tabular}

Source: Federal Customs Service of Russia (2017)

Table 5

The product groups affected by import ban in 2016

\begin{tabular}{|l|c|c|c|c|c|c|c|c|c|c|c|c|}
\hline & \multicolumn{2}{|c|}{ EU } & \multicolumn{2}{|c|}{ Australia } & \multicolumn{2}{c|}{ Canada } & \multicolumn{2}{c|}{ Norway } & \multicolumn{2}{c|}{ USA } & \multicolumn{3}{c|}{ Total } \\
\cline { 2 - 16 } & $\begin{array}{c}\text { million } \\
\text { USD }\end{array}$ & $\%$ & $\begin{array}{c}\text { million } \\
\text { USD }\end{array}$ & $\%$ & $\begin{array}{c}\text { million } \\
\text { USD }\end{array}$ & $\%$ & $\begin{array}{c}\text { million } \\
\text { USD }\end{array}$ & $\%$ & $\begin{array}{c}\text { million } \\
\text { USD }\end{array}$ & $\%$ & $\begin{array}{c}\text { million } \\
\text { USD }\end{array}$ & $\%$ \\
\hline $02-$ Meat & 0,504 & $0 \%$ & 0 & $0 \%$ & 0 & $0 \%$ & 0,0325 & $24 \%$ & 0 & $0 \%$ & $\mathbf{0 , 5 3 6}$ & $\mathbf{0} \%$ \\
\hline 03 - Fish & 63,904 & $9 \%$ & 0 & $0 \%$ & 0 & $0 \%$ & 0,0042 & $3 \%$ & 0,1278 & $5 \%$ & $\mathbf{6 4 , 0 3 6}$ & $\mathbf{9} \%$ \\
\hline $04-$ Milk & 3,307 & $0 \%$ & 0 & $0 \%$ & 0 & $0 \%$ & 0,0183 & $14 \%$ & 0,9786 & $40 \%$ & $\mathbf{4 , 3 0 4}$ & $\mathbf{1} \%$ \\
\hline 07 - Vegetables & 58,608 & $9 \%$ & 0 & $0 \%$ & 0,195 & $50 \%$ & 0,0084 & $6 \%$ & 0,3959 & $16 \%$ & $\mathbf{5 9 , 2 0 8}$ & $\mathbf{9 \%}$ \\
\hline 08 - Fruits & 69,666 & $10 \%$ & 0 & $0 \%$ & 0 & $0 \%$ & 0,0018 & $1 \%$ & 0,7268 & $30 \%$ & $\mathbf{7 0 , 3 9 4}$ & $\mathbf{1 0} \%$ \\
\hline $\begin{array}{l}16,19,21-\text { Food } \\
\text { prep. }\end{array}$ & 487,412 & $71 \%$ & 0,0039 & $100 \%$ & 0,192 & $50 \%$ & 0,0676 & $51 \%$ & 0,2239 & $9 \%$ & $\mathbf{4 8 7 , 8 9 9}$ & $\mathbf{7 1} \%$ \\
\hline Total & $\mathbf{6 8 3 , 4 0 2}$ & $\mathbf{1 0 0} \%$ & $\mathbf{0 , 0 0 3 9}$ & $\mathbf{1 0 0} \%$ & $\mathbf{0 , 3 8 7}$ & $\mathbf{1 0 0} \%$ & $\mathbf{0 , 1 3 2 9}$ & $\mathbf{1 0 0} \%$ & $\mathbf{2 , 4 5 3 2}$ & $\mathbf{1 0 0} \%$ & $\mathbf{6 8 6 , 3 7 9}$ & $\mathbf{1 0 0} \%$ \\
\hline
\end{tabular}

Source: Federal Customs Service of Russia (2016), UN Comtrade 2017

As a result of the import ban, the share of selected countries in Russian agrarian imports of products under the ban had decreased (2013 vs. 2016). The applied import ban had already affected individual 
countries in 2014 (the first year of sanctions). In 2014 alone, the share of the EU in Russian imports affected by the ban had decreased from $28 \%$ to $17 \%$, and the share of Norway had decreased from $5 \%$ to 3\%. During 2015 and 2016 the share of individual countries affected by the ban in Russian imports of products had decreased by even more. In 2016 the share of the EU had only reached $6.8 \%$, the share of Norway had decreased to $0.001 \%$, the share of Canada had only reached $0.003 \%$, the share of the USA had decreased to $0.58 \%$, and the share of Australia had decreased to only $0.0001 \%$. On the other hand, the trade performance of some other countries had increased (for details see Table 6).

Table 6

Top 20 countries of exports to Russia (products under the applied import ban)

\begin{tabular}{|l|c|c|c|c|c|c|}
\hline & $\begin{array}{c}\text { Import 2013 } \\
\text { (in USD) }\end{array}$ & $\begin{array}{c}\text { Import in 2013 } \\
\text { in kg }\end{array}$ & $\begin{array}{c}\text { Import 2016 } \\
\text { (in USD) }\end{array}$ & $\begin{array}{c}\text { Import in 2016 } \\
\text { in kg }\end{array}$ & $\begin{array}{c}\text { Difference } \\
2013 / 2016 \text { (import } \\
\text { value in USD) }\end{array}$ & $\begin{array}{c}\text { Difference } \\
\text { volume in } \mathrm{kg} \text { ) }\end{array}$ \\
\hline Serbia & $140,151,272$ & $141,260,912$ & $263,845,505$ & $306,651,817$ & $123,694,233$ & $165,390,905$ \\
\hline China & $906,933,648$ & $823,070,642$ & $1,029,074,545$ & $834,457,330$ & $122,140,897$ & $11,386,688$ \\
\hline Azerbaijan & $210,164,498$ & $264,646,961$ & $293,812,717$ & $185,825,428$ & $83,648,219$ & $-78,821,533$ \\
\hline Ecuador & $578,895,774$ & $1,319,345,286$ & $604,949,302$ & $1,364,297,209$ & $26,053,528$ & $44,951,923$ \\
\hline Kyrgyzstan & $6,231,010$ & $7,464,384$ & $31,816,165$ & $28,730,568$ & $25,585,155$ & $21,266,184$ \\
\hline India & $100,242,147$ & $105,663,692$ & $125,291,689$ & $73,094,017$ & $25,049,542$ & $-32,569,675$ \\
\hline TFYR of & $7,523,685$ & $9,459,356$ & $28,757,408$ & $47,483,853$ & $21,233,723$ & $38,024,497$ \\
\hline Macedonia & $8,050,198$ & $12,325,376$ & $25,614,581$ & $31,729,376$ & $17,564,383$ & $19,404,000$ \\
\hline Georgia & 821,112 & 889,485 & $16,231,722$ & $19,196,155$ & $15,410,610$ & $18,306,670$ \\
\hline Bosnia & $11,568,335$ & $4,999,329$ & $20,185,274$ & $13,039,233$ & $8,616,939$ & $8,039,904$ \\
\hline Herzegovina & $5,943,004$ & $14,205,402$ & $13,837,660$ & $5,412,764$ & $7,894,656$ & $-8,792,638$ \\
\hline Malaysia & $16,026,796$ & $36,539,868$ & $22,309,011$ & $41,763,671$ & $6,282,215$ & $5,223,803$ \\
\hline Colombia & $2,669,082$ & $6,522,916$ & $8,107,905$ & $9,091,680$ & $5,438,823$ & $2,568,764$ \\
\hline Costa Rica & $68,532,134$ & $48,667,552$ & $73,726,309$ & $99,987,899$ & $5,194,175$ & $51,320,347$ \\
\hline Mexico & 499,860 & 670,885 & $3,363,873$ & $1,124,998$ & $2,864,013$ & 454,113 \\
\hline Armenia & $3,450,975$ & $2,707,554$ & $5,620,590$ & $5,074,847$ & $2,169,615$ & $2,367,293$ \\
\hline Albania & 472,727 & 58,034 & $1,712,198$ & 122,876 & $1,239,471$ & 64,842 \\
\hline Algeria & 394,623 & $2,455,988$ & $1,404,560$ & 572,400 & $1,009,937$ & $-1,883,588$ \\
\hline Sri Lanka & 13,181 & 58,615 & 497,075 & $35,723,502$ & 483,894 & $35,664,887$ \\
\hline Mongolia & $2,791,908$ & $2,313,782$ & $3,126,356$ & $2,569,516$ & 334,448 & 255,734 \\
\hline Mozambique & & & & & & \\
\hline Jordan & & & & & & \\
\hline
\end{tabular}

Source: UN Comtrade 2017.

\section{The impact of the applied ban on EU's exports to Russian Federation}

The subsequent part of this paper provides an overview of the applied import ban on EU agricultural exports. The European Union is considered the most affected region by the applied ban. The EU export of banned items was reduced from 6.5 billion USD to less than 700 million USD. The tables 7-11 provide an overview the impact of the applied ban on EU vegetable, fruit, dairy and dairy products, meat and meat products and fish exports (see Appendix).

Between 2013 and 2016, the total value of EU exports of vegetables to Russia decreased by $94 \%$ in terms of value, and by $95 \%$ in terms of quantity. The most affected products were tomatoes (decreased by 199 thousand tonnes), cabbage (decreased by 118 thousand tonnes), carrots (decreased by 91 thousand tonnes), and potatoes (decreased by 80 thousand tonnes). The most affected countries of the applied ban are the following: the Netherlands, Spain, Poland and Belgium. On the other hand, the winners of the applied ban are China, Turkey, Belarus, and Egypt. These countries managed to replace European exports to Russia. This is especially true in the case of tropical and subtropical production. It means the applied ban not only reduced EU's exports of its own production, but it also affected re-exports. 
In the first place, the Russian ban affected the perishable products/fruit sector. For several EU countries, Russia was traditionally an important destination for EU fruit. Russia represented about 30\% of the EU's fruit exports in 2013. The main products concerned were apples, peaches, nectarines and pears. The main EU suppliers of fruits were Poland, Spain, Greece, Italy and Belgium. In the period 2013-2016, European fruit export was reduced from 1,519 million USD to nearly 70 million USD. The value of exports was reduced by $95 \%$ and export volume was reduced by $97 \%$ (from 1538 to 40 tons). Countries that were most affected by the ban were the following: the Netherlands, Spain, Italy, Poland and Germany. Belarus and Serbia took advantage of not being involved in the trade war and they are retrading food products between EU and Russia.

Other EU exports that were significantly affected by the Russian import ban are represented by Meat and meat products. The volume and value of exported meat were reduced by nearly $100 \%$. The value of exports was reduced from 1,548 million USD to only 0.5 million USD and the volume was cut from 472 thousand tonnes to 98 tonnes. The import ban affected trade in all kinds of meat. This significant export reduction particularly affected the trade in pig meat and the trade in poultry meat. The pork meat trade was reduced from 1,548 million USD to 0.5 million USD. The poultry meat trade was reduced from 95 million USD to 32 ths. USD. To compensate for missing imports from the EU, Russia increased imports of meat from Brazil, Belarus, Turkey, Argentina, and Serbia. In addition, the significant part of those imports is represented by re-exports originating from EU countries. Because of constantly increasing reexports from Serbia and Belarus, Russia decided to change its attitude towards bilateral trade agreements.

The ban applied to fish imports did not affect EU trade performance so much as bans applied to other commodity imports. In the period from 2013 to 2016, the value of EU exports was reduced from 216 million USD to cc 64 million USD. Trade volume was reduced from cc115 thous. tons to cc 24 thous. tons. While in the case of other types of commodities, the EU may be considered the most affected subject of the applied import ban. In the case of the fish trade, the most affected country, Norway, is not an EU member.

The applied Russian import ban significantly hurt one of the weakest sectors of the EU agricultural and foodstuff industry - the dairy sector. The EU dairy market is suffering because of chronic problems related to its instability due to production imbalances. Making matters worse, is that just before the ban was applied, EU countries were in the process of a dairy market transformation. Between 2013 and 2016, the applied ban reduced EU dairy exports to Russia from 1,738 million USD/year to cc 3 million USD/year. The exported volume was reduced from 417 thous. tons to only 620 tons. The most affected segments of the dairy trade are the following: cheese and curd (export value reduction by 1,272 million USD), butter and milk fats (within an analysed time period - the export value was reduced from 184 million USD to less than 100 this. USD. Countries suffering due to the applied ban are Russia's neighbours to the west; Finland, Poland and the Baltic countries. Because of the low level of Russian dairy production performance and its inability to satisfy domestic demand, Russia substituted EU products by imports from the following countries: Argentina, Belarus, and Kazakhstan (Exports from some countries are not represented by their own production, but it is only a re-export. It is evident especially in the case of Belarus).

Table 7 provides an estimation-overview of the expected impact of the applied ban on EU agricultural trade. The processed table (processed table doesn't exist-should be analysed) provides an estimation of differences between the theoretical value of trade performance (based on trade development in the period before the ban was applied) and the current trade performance (2016). 
Table 7

The estimated real impact of the applied ban on European agricultural exports

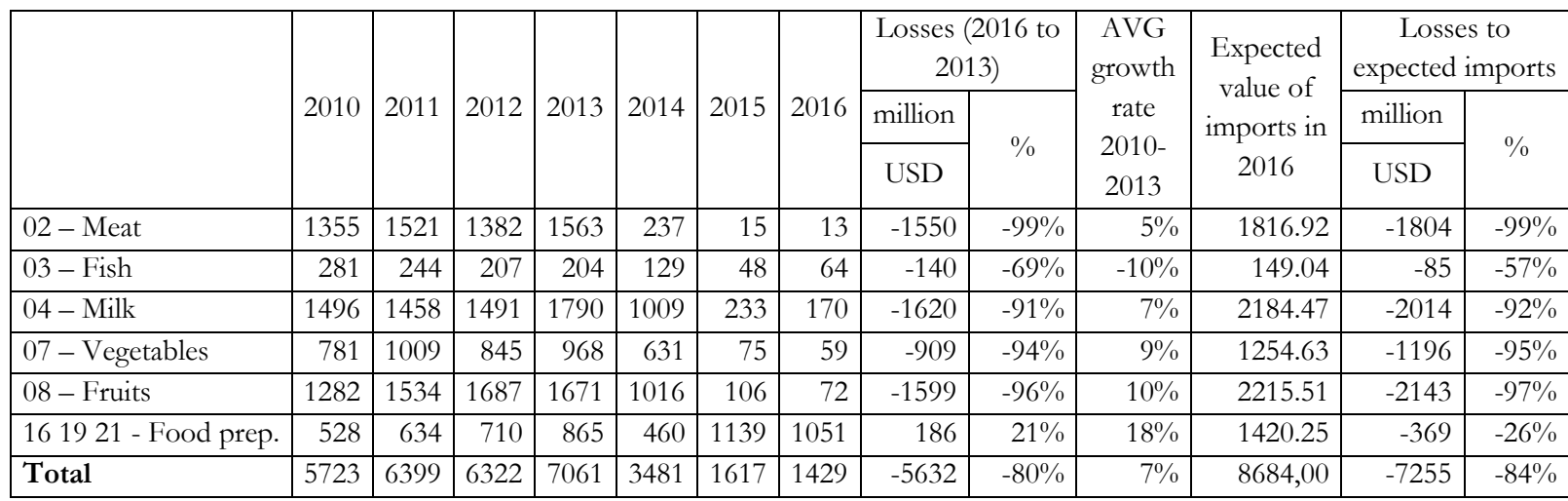

Source: Comtrade database Federal Customs Service of Russia (2017)

Table 8

The non-affected part of EU agrarian exports to the Russian Federation

\begin{tabular}{|c|c|c|c|c|c|c|c|c|c|}
\hline \multirow[b]{2}{*}{ HS system } & \multirow[t]{2}{*}{2010} & \multirow[t]{2}{*}{2011} & \multirow[t]{2}{*}{2012} & \multirow[t]{2}{*}{2013} & \multirow[t]{2}{*}{2014} & \multirow[t]{2}{*}{2015} & \multirow[t]{2}{*}{2016} & \multicolumn{2}{|c|}{$\begin{array}{c}\text { Losses } \\
\text { (2016 to 2013) }\end{array}$} \\
\hline & & & & & & & & Million USD & $\%$ \\
\hline 01 - Live animals & 245 & 321 & 207 & 114 & 141 & 121 & 116 & 2 & $2 \%$ \\
\hline $05-$ Animal originated products & 52 & 57 & 52 & 47 & 28 & 21 & 23 & -24 & $-51 \%$ \\
\hline $06-$ Cut flowers & 447 & 551 & 593 & 630 & 544 & 456 & 398 & -232 & $-37 \%$ \\
\hline 09 - Coffee, tea, mate, spices & 146 & 184 & 184 & 227 & 235 & 178 & 230 & 3 & $1 \%$ \\
\hline $10-$ Cereals & 88 & 211 & 150 & 214 & 206 & 135 & 101 & -113 & $-53 \%$ \\
\hline 11 - Products of milling industry & 73 & 103 & 112 & 98 & 108 & 72 & 88 & -10 & $-10 \%$ \\
\hline $12-$ Oil seeds & 266 & 385 & 406 & 425 & 355 & 293 & 376 & -49 & $-11 \%$ \\
\hline 13 - Lack, gums, resins & 101 & 102 & 91 & 100 & 97 & 83 & 88 & -12 & $-12 \%$ \\
\hline $14-$ Vegetable planting materials & 0 & 1 & 1 & 0 & 0 & 0 & 1 & 0 & $48 \%$ \\
\hline 15 - Animal and vegetable fats \& oils & 300 & 393 & 350 & 325 & 379 & 211 & 257 & -68 & $-21 \%$ \\
\hline 17 - Sugars and sugar confectionery & 142 & 128 & 156 & 159 & 162 & 122 & 131 & -28 & $-18 \%$ \\
\hline 18 - Cocoa and cocoa preparations & 493 & 562 & 531 & 556 & 601 & 418 & 573 & 17 & $3 \%$ \\
\hline 20 - Preparations of vegetables, fruit and nuts & 481 & 529 & 562 & 595 & 644 & 420 & 440 & -155 & $-26 \%$ \\
\hline $22-$ Beverages and spirits & 1265 & 1681 & 1888 & 2068 & 1878 & 1062 & 995 & -1073 & $-52 \%$ \\
\hline 23 - Food industry waste and prepared animal fodder & 621 & 729 & 718 & 752 & 728 & 529 & 525 & -228 & $-30 \%$ \\
\hline 24 - Tobacco and manufactured tobacco substitutes & 179 & 188 & 187 & 186 & 232 & 260 & 398 & 212 & $114 \%$ \\
\hline Total & 4899 & 6125 & 6186 & 6495 & 6339 & 4379 & 4738 & -1757 & $-27 \%$ \\
\hline
\end{tabular}

Source: Comtrade database Federal Customs Service of Russia (2017)

As can be seen from the calculations, in recent years there has been an upward trend of growth in imports of agricultural products in almost all commodity groups (except for fish and crustaceans). On average, imports grew by $7 \%$ per year. Therefore, if Russia had not taken the decision to apply an import ban on products from the EU, the value of food exports could have increased to 8,684 million USD. Thus, taking into account the benefits, the reduction in import value amounted to 7,255 million USD. It is necessary, however, to highlight the impact of the Russian policy on that part of agricultural trade not on the import ban list. The value of EU exports in items not included in the import ban list was reduced from 6,495 million USD in 2013 to 4,738 million USD in 2016 (by 27\%). The most affected exports items (not listed in the import ban) are the following: beverages and spirits, food industry residues and waste, animal fodder, preparations of vegetables and fruit and nuts, cut flowers and cereals. 
The final part of this paper is dedicated to Russian agricultural trade competitiveness analyses. The table available in appendix (Appendix Table A1), provides an overview of LFI index analyses between 2013 (before applied import ban) and 2016 (the third year of applied ban). This table details the basic changes in the LFI index for approximately forty-eight commodity items representing trade in agricultural and foodstuff products under the applied import ban.

The following items dispose by comparative advantages according to LFI analysis:
0303 - fish frozen
$(\mathrm{LFI}=10.59)$
0306 - crustaceans live fresh etc. and cooked
$(\mathrm{LFI}=7.91)$
0304 - fish fillets \& other fish meat
$(\mathrm{LFI}=3.48)$
0713 - leguminous vegetables dried shelled
$(\mathrm{LFI}=3.15)$
0307 - molluscs \& aquatic invertebrates
$(\mathrm{LFI}=0.72)$
0401 - milk and cream, not conc. or sweetened
$(\mathrm{LFI}=0.52)$
0305 - fish dried salted etc. smoked etc.
$(\mathrm{LFI}=0.46)$
0802 - nuts nes
$(\mathrm{LFI}=0.20)$
0709 - vegetables nes
$(\mathrm{LFI}=0.17)$
1601 - sausages similar prdt meat
$(\mathrm{LFI}=0.11)$
0403 - buttermilk yogurt kefir etc.
$(\mathrm{LFI}=0.09)$
0710 - vegetables (raw or cooked by steam)
$(\mathrm{LFI}=0.04)$
0711 - vegetables, temporarily preserved
$(\mathrm{LFI}=0.01)$
0807 - melons and papayas
$(\mathrm{LFI}=0.01)$

During the analysed years, agricultural exports improved their comparative advantages in the case of sixteen commodity items. About thirty items recorded the reduction of comparative advantages. Items increasing their comparative advantages are the following: 0306 - crustaceans live fresh, 0304 - fish fillets \& other fish meat, 0713 - leguminous vegetables, dried shelled, 0302 - fish, fresh or chilled, 0307 molluscs \& aquatic invertebrates, 0802 - nuts, 0709 - vegetables and 0401 - milk and cream, not conc.(maybe not concentrated) or sweetened. Conversely, the most significant comparative advantages reduction was recorded in the case of the following items: 0303 - fish, frozen, 0805 - citrus fruit, 0402 milk and cream, conc. or sweetened, 0803 - Bananas and plantains, 0405 - butter and other milk fats and oils, 0406 - cheese and curd, 0201 - meat of bovine animals, fresh or chilled, 0202 - meat of bovine animals, frozen, 0808 - apples, pears and quinces, 0403 - buttermilk, yogurt, kefir etc., 0401 - milk and cream, not conc. or sweetened. While the applied import ban improved Russian trade competitiveness, especially in the area of fish trade; in the case of meat, dairy products, fruits and vegetables, the applied ban was not able to improve comparative advantages. However, Russia has improved competitiveness not only at the level of Russian national market but also at the level of post-soviet countries (Community of the Independent States and Eurasian Economic Union) as a result of the applied ban.

\section{EMPIRICAL RESULTS AND DISCUSSION}

The import ban is a political and economic sanction that is contradictory to the principles of free trade. From the perspective economic theory, economic sanctions provide for suboptimal resource allocation and create welfare loss in aggregate. The import embargo has redistributional effects on both the sanctioning and target countries (Kaempfer \& Lowenberg, 2007). The primary finding is that Russia bears the highest income loss, while the EU recovers part of its lost trade through the expansion of exports to other markets (Boulanger et al., 2016). Economic theory also considers households' behavioural aspects by finding an answer to the question of whether commercialized households could make a greater contribution to national food security in Russia (Wegren, 2015). 
Economic recession and restrictions on foreign trade in food caused increasing vulnerability of Russian households to food insecurity. A regression-based analysis revealed that sustainability of the food supply in Russia is threatened by inflation and a decreasing purchasing power. People are shifting towards purchasing cheaper products of lower quality, while exporters seek higher profits outside the country and thus create food shortages in the domestic market (Erokhin, 2017). The Russian Federation faces a new economic crisis associated with the termination of public investments. Thus, the most promising new strategy to overcome the crisis could be an increase in food products (exports) to Asian and African countries (Koptseva \& Kirko, 2017).

One of the key impacts of the sanctions on food products supply and agricultural policy in Russia was the dynamic growth of prices on the importation of banned food products in the internal Russian market compared to the inflation rate. To cover the food shortage, Russia started or expanded collaboration with other international partners, e.g. Brazil, Belorussia, Paraguay, Argentina and Iran (meat), Ecuador, Pakistan, Morocco, China (fruit), Egypt, the Republic of South Africa, Israel, Azerbaijan (vegetables) etc. (Kapsdorferová \& Sviridova, 2016).

The import ban has also had an impact on Russian agricultural policy in the form of increased federal expenditures on the realisation of the agricultural development programme until 2020. The aim of the agricultural development programme is to support successful agricultural enterprises in an attempt to establish an internal market of Russian agricultural raw materials and food products by 2020 and to expand to external markets with high-quality natural products (Kapsdorferová \& Sviridova, 2016).

There are many effects of the Russian agrarian import ban from the perspective of the EU. Russia was the second most important destination for EU Agri-Food sector exports, after the USA. The economic literature shows that the effectiveness of an import ban can be doubtful, as the target country may redirect exports to third countries and/or also engage in triangular activities to bypass custom controls (Drezner, 2000; Kutlina-Dimitrova, 2017). Agrarian foreign trade statistics show that the export of banned agricultural products has been redirected towards new markets. Moreover, the European Commission started to extend support measures for the dairy, fruit and vegetable sectors affected by Russia's ban and has managed to compensate the losses in export sales to Russia by increasing exports to other main destinations and alternative markets, such as the USA, China, Switzerland, key Asian and Arabic markets (Kapsdorferová \& Sviridova, 2016). The impact of the Russian import ban is countryspecific, as was empirically studied e.g. in Hungary (Sági \& Nikulin, 2017), Poland (Goliński et al., 2016) or Lithuania (Stankaityte, 2016). Nevertheless, the overall impact on GDP is marginal (Mo, 2016).

\section{CONCLUSION}

The Agrarian and foodstuff products import ban applied by the Russian Federation in relation to the USA, Canada, Norway, Australia and especially the European Union, significantly changed the characteristics of mutual trade in agricultural products. The value of agricultural imports from the affected countries was reduced by 66\% (between 2013 and 2016). This significant import reduction not only affected imports coming from countries under the ban, but also imports from other countries recorded a reduction by $22 \%$. The applied ban could be understood as part of a broader strategy to reduce Russian food dependency on imports of agricultural and foodstuff products. It is evident that the applied ban and other Russian governmental related activities are changing the Russian agricultural market structure and making Russia stronger and more independent. This is especially true in those products which could be produced in a local climate condition. The applied ban especially affected those imports which could be considered competitors for national production capacities (meat and meat products; dairy and dairy products; fruit and vegetable; fish). The potential to substitute those items by local production is evident. The applied ban reduced imports not only from affected countries but also from the rest of the world by $35 \%$. Of course, imports coming from countries operating under the ban were affected much more in 
comparison to others, but regardless, the applied Russian policy affected the whole import structure. This means that the Russian applied policy not only affected the importation of banned items, but also affected trade in other items and it reduced Russian food dependency on the European Union and other countries. This may be considered as evidence of a broader Russian strategy to support its own Agri-Food production capacities and food self-sufficiency.

The most affected region of the Russian import ban is undoubtedly the European Union. The applied ban affected imports especially from Lithuania, Germany, the Netherlands, Denmark, Spain, Belgium, Finland and France. The most affected countries, in relation to the share of Russian imports in their trade performance, the most affected countries are Lithuania, Latvia, Estonia, Finland and Poland.

Even though the Russian Federation was able to substitute a significant portion of reduced imports by domestic production; it was not able to substitute the full volume of banned imports. The applied ban resulted in changes in Russian agricultural trade territorial structure. To satisfy domestic demand, Russia increased food imports especially from Serbia, China, Azerbaijan, Ecuador, Kyrgyzstan, India, Macedonia, Georgia, Bosnia and Malaysia. A negative feature of the applied ban for Russian consumers was the reduction of food heterogeneity, the increase in food prices, and the reduction of competitiveness and available food quality reduction.

Because the Russian import ban was applied in the year 2017 and it is expected to be applied until at least the end of the year 2019, it is possible to expect an even more significant EU-Russian agricultural trade reduction and changes in the territorial and commodity structure. For the European, Union-Russian market is already not as attractive as it was in the past and many EU countries have decided to change their trade policies in relation to Russia.

\section{ACKNOWLEDGEMENT}

This paper is supported by a grant project of the Internal Grant Agency of the Faculty of Economics and Management Czech University of Life Sciences, Prague. The project title is „, Influence of economic sanctions and embargo on agricultural sector in Russian Federation and European Union (20181017)”

\section{REFERENCES}

Boulanger, P., Dudu, H., Ferrari, E., \& Philippidis, G. (2016). Russian roulette at the trade table: a specific factors CGE analysis of an agri-food import ban. Journal of Agricultural Economics, 67(2), 272-291.

Drezner, D. W. (2000). Bargaining, enforcement, and multilateral sanctions: when is cooperation counterproductive?. International Organization, 54(1), 73-102.

GSPI. (2018). The doctrine of Food Security of RF 2009. Retrieved from http://government.ru/docs/16916/

Erokhin, V. (2017). Factors influencing food markets in developing countries: An approach to assess sustainability of the food supply in Russia. Sustainability, 9(8), 1313.

Erokhin, V., Ivolga, A., \& Heijman, W. J. M. (2014). Trade liberalization and state support of agriculture: effects for developing countries. Agricultural Economics, 60(11), 524-537.

Goliński, B., Komur, M., \& Guth, M. (2016). Consequences of Russian Embargo for Polish Agricultural Market and Potential Distribution Channels of Polish Food Products Covered by Russian Embargo. Roczniki Ekonomiczne Kujawsko-Pomorskiej Szkoly Wyższej w Bydgoszczy, (9), 523-537.

Ishchukova, N. (2015). The Formation of Russian Agrarian Trade Structure: Inter-industry vs. Intra-industry Trade Activities. Acta Universitatis Agriculturae et Silviculturae Mendelianae Brunensis, 62(6), 1293-1299.

Kaempfer, W. H., \& Lowenberg, A. D. (2007). The political economy of economic sanctions. Handbook of defense economics, 2, 867-911. 
Kapsdorferová, Z., \& Sviridova, O. (2016). Impact of sanctions on agricultural policy in European Union and Russia. International Scientific Days 2016. The Agri-Food Value Chain: Challenges for Natural Resources Management and Society, 190-200.

Kastakova, E. (2012). The impact of comparative advantages in the deepening mutual foreign trade relations between the Slovakia and Russia. Ekonomicky Casopis, 60(7), 746-762.

Koptseva, N. P., \& Kirko, V. I. (2017). Development of the Russian Economy's Agricultural Sector Under the Conditions of Food Sanctions (2015-2016). Journal of Environmental Management \& Tourism, 8(1 (17)), 123.

Kutlina-Dimitrova, Z. (2017). The economic impact of the Russian import ban: a CGE analysis. International Economics and Economic Policy, 14(4), 537-552.

Mo, Y. (2016). Assessment of Russian Embargo Impact on Economies of the EU Countries - An Input-Output Approach Degree project/SLU Department of Economic, Swedish University of Agricultural Sciences Uppsala.

Sági, J., \& Nikulin, E. E. (2017). The economic effect of Russia imposing a food embargo on the European Union with Hungary as an example. Studies in Agricultural Economics, 119(1316-2017-1546), 85.

Stankaityte, B. (2016). Competitiveness of dairy products export to Russia and alternative markets. Management Theory and Studies for Rural Business and Infrastructure Development, 38(4), 425-435.

Lubos, S., Jindrich, S., Natalia, I., \& Richard, S. (2016). Agrarian import ban and its impact on the Russian and European Union agrarian trade performance. Agricultural Economics, 62(11), 493-506.

Svatoš, M., Smutka, L., \& Ishchukova, N. (2014). The position of agriculture in the Russian Federation-the last two decades development overview. Agricultural Economics, 60(11), 489-502.

Wegren, S. K. (2014). The Russian food embargo and food security: can household production fill the void?. Eurasian geography and economics, 55(5), 491-513.

Zaghini, A. (2003). Trade advantages and specialisation dynamics in acceding countries. Working paper [№ 249], European central bank, Frankfurt am Main Germany, 4-15. 


\section{APPENDIX}

Table A1

EU vegetable exports to Russia

\begin{tabular}{|c|c|c|c|c|c|c|c|c|}
\hline & \multicolumn{4}{|c|}{ Value, in millions of USD } & \multicolumn{4}{|c|}{ Quantity, thousand tonnes } \\
\hline & \multirow[b]{2}{*}{2013} & \multirow[b]{2}{*}{2016} & \multicolumn{2}{|c|}{2014 to 2016} & \multirow[b]{2}{*}{2013} & \multirow[b]{2}{*}{2016} & \multicolumn{2}{|c|}{2014 to 2016} \\
\hline & & & $\begin{array}{l}\text { million } \\
\text { USD }\end{array}$ & $\%$ & & & $\begin{array}{c}\text { thousand } \\
\text { tonnes }\end{array}$ & $\%$ \\
\hline EU exports of banned vegetables to Russia & 935 & 58.61 & -876.39 & $-94 \%$ & 905 & 46.89 & -858.11 & $-95 \%$ \\
\hline 0701 - potatoes & 50 & 8.16 & -41.84 & $-84 \%$ & 92 & 11.48 & -80.52 & $-88 \%$ \\
\hline 0702 - tomatoes & 292 & 21.54 & -270.46 & $-93 \%$ & 211 & 11.69 & -199.31 & $-94 \%$ \\
\hline 0703 - onions, shallots, garlic, leeks & 56 & 15.87 & -40.13 & $-72 \%$ & 86 & 18.01 & -67.99 & $-79 \%$ \\
\hline 0704 - cabbages, cauliflower, kale & 85 & 0.03 & -84.97 & $-100 \%$ & 118 & 0.04 & -117.96 & $-100 \%$ \\
\hline 0705 - lettuce and chicory & 47 & 0.06 & -46.94 & $-100 \%$ & 33 & 0.08 & -32.92 & $-100 \%$ \\
\hline 0706 - carrots, turnips \& other edible roots & 51 & 0.07 & -50.93 & $-100 \%$ & 91 & 0.08 & -90.92 & $-100 \%$ \\
\hline 0707 - cucumbers and gherkins & 57 & 0.06 & -56.94 & $-100 \%$ & 35 & 0.06 & -34.94 & $-100 \%$ \\
\hline 0708 - leguminous vegetables, fr or chill & 0.04 & 0.36 & 0.32 & $811 \%$ & 0.02 & 0.09 & 0.07 & $340 \%$ \\
\hline 0709 - vegetables nesoi & 205 & 3.02 & -201.98 & $-99 \%$ & 121 & 1.55 & -119.45 & $-99 \%$ \\
\hline 0710 - vegetables (raw or cooked by steam) & 77 & 0.07 & -76.93 & $-100 \%$ & 111 & 0.04 & -110.96 & $-100 \%$ \\
\hline 0711 - vegetables, temporarily preserved & 0 & 0.03 & 0.03 & $\mathrm{x}$ & 0 & 0.02 & 0.02 & $\mathrm{x}$ \\
\hline 0712 - vegetables, dried, whole, cut & 9.2 & 4.75 & -4.45 & $-48 \%$ & 2.8 & 0.45 & -2.35 & $-84 \%$ \\
\hline 0713 - leguminous vegetables, dried shelled & 5.4 & 4.59 & -0.81 & $-15 \%$ & 3.5 & 3.32 & -0.18 & $-5 \%$ \\
\hline
\end{tabular}

Source: Federal Customs Service of Russia (2017)

Table A2

Test Fruits exported from the countries of the European Union to Russia

\begin{tabular}{|c|c|c|c|c|c|c|c|c|}
\hline & \multicolumn{4}{|c|}{ Value, in millions of USD } & \multicolumn{4}{|c|}{ Quantity, thousand tonnes } \\
\hline & \multirow[b]{2}{*}{2013} & \multirow[b]{2}{*}{2016} & \multicolumn{2}{|c|}{2016 to 2013} & \multirow[b]{2}{*}{2013} & \multirow[b]{2}{*}{2016} & \multicolumn{2}{|c|}{2016 to 2013} \\
\hline & & & $\begin{array}{c}\text { million } \\
\text { USD }\end{array}$ & $\%$ & & & thousand tonnes & $\%$ \\
\hline EU exports of banned fruits to Russia & 1519 & 69.67 & -1449.33 & $-95 \%$ & 1538 & 39.75 & -1498.25 & $-97 \%$ \\
\hline 0801 - coconuts brazil nuts \& cashew nuts & 0.23 & 0.00 & -0.23 & $-100 \%$ & 0.02 & 0.00 & -0.02 & $-100 \%$ \\
\hline 0802 - nuts nesoi & 5.43 & 4.49 & -0.94 & $-17 \%$ & 0.69 & 0.44 & -0.25 & $-36 \%$ \\
\hline 0803 - Bananas and plantains & 0.06 & 0.10 & 0.04 & $68 \%$ & 0.01 & 0.02 & 0.01 & $139 \%$ \\
\hline 0804 - dates figs pineapples avocados & 2.55 & 21.02 & 18.47 & $724 \%$ & 0.5 & 10.63 & 10.13 & $2025 \%$ \\
\hline 0805 - citrus fruit & 147 & 14.19 & -132.81 & $-90 \%$ & 134 & 12.01 & -121.99 & $-91 \%$ \\
\hline 0806 - grapes & 61 & 6.36 & -54.64 & $-90 \%$ & 33 & 2.97 & -30.03 & $-91 \%$ \\
\hline 0807 - melons and papayas & 2.9 & 3.04 & 0.14 & $5 \%$ & 2.5 & 2.55 & 0.05 & $2 \%$ \\
\hline 0808 - apples pears and quinces & 706 & 4.15 & -701.85 & $-99 \%$ & 984 & 5.04 & -978.96 & $-99 \%$ \\
\hline 0809 - apricots cherries peaches plums & 327 & 3.91 & -323.09 & $-99 \%$ & 217 & 1.72 & -215.28 & $-99 \%$ \\
\hline 0810 - fruit nesoi & 224 & 11.13 & -212.87 & $-95 \%$ & 118 & 4.03 & -113.97 & $-97 \%$ \\
\hline 0811 - fruit \& nuts (raw or cooked by steam) & 34 & 0.38 & -33.62 & $\mathrm{x}$ & 47 & 0.19 & -46.81 & $\mathrm{x}$ \\
\hline 0812 - fruit \& nuts temporarily preserved & 0.1 & 0.00 & -0.10 & $-100 \%$ & 0.2 & 0.00 & -0.20 & $-100 \%$ \\
\hline 0813 - fruit dried nesoi & 8.6 & 0.90 & -7.70 & $-90 \%$ & 0.8 & 0.15 & -0.65 & $-81 \%$ \\
\hline
\end{tabular}

Source: Federal Customs Service of Russia (2017) 
Meat exports from the countries of the European Union to Russia

\begin{tabular}{|c|c|c|c|c|c|c|c|c|}
\hline & & Value $\mathrm{i}$ & illions of USI & & & Quat & ity thousand tonn & \\
\hline & & & 2016 tc & 013 & & & 2016 to 2 & \\
\hline & 2013 & 2016 & million USD & $\%$ & 2013 & 2016 & thousand tonnes & $\%$ \\
\hline EU exports of banned meat to Russia & 1548 & 0.504 & -1547.50 & $-100 \%$ & 472 & 0.098 & -471.90 & $-100 \%$ \\
\hline $\begin{array}{l}0201 \text { - meat of bovine animals fresh or } \\
\text { chilled }\end{array}$ & 68 & 0.004 & -68.00 & $-100 \%$ & 14 & 0.000 & -14.00 & $-100 \%$ \\
\hline 0202 - meat of bovine animals frozen & 77 & 0.052 & -76.95 & $-100 \%$ & 18 & 0.021 & -17.98 & $-100 \%$ \\
\hline 0203 - meat of swine (pork) & 1305 & 0.140 & -1304.86 & $-100 \%$ & 365 & 0.015 & -364.98 & $-100 \%$ \\
\hline 0207 - meat \& ed offal of poultry & 95 & 0.032 & -94.97 & $-100 \%$ & 72 & 0.050 & -71.95 & $-100 \%$ \\
\hline 0210 - meat \& ed offal salted dried & 3.6 & 0.276 & -3.32 & $-92 \%$ & 0.6 & 0.012 & -0.59 & $-98 \%$ \\
\hline
\end{tabular}

Source: Federal Customs Service of Russia (2017)

Fish exports from the countries of the European Union to Russia

\begin{tabular}{|c|c|c|c|c|c|c|c|c|}
\hline & \multicolumn{4}{|c|}{ Value in millions of USD } & \multicolumn{4}{|c|}{ Quantity thousand tonnes } \\
\hline & \multirow{2}{*}{2013} & \multirow{2}{*}{2016} & \multicolumn{2}{|c|}{2016 to 2013} & \multirow{2}{*}{2013} & \multirow{2}{*}{2016} & \multicolumn{2}{|c|}{2016 to 2013} \\
\hline & & & million USD & $\%$ & & & thousand tonnes & $\%$ \\
\hline EU exports of banned fish to Russia & 216.10 & 63.90 & -152.20 & $-70 \%$ & 114.70 & 23.69 & -91.01 & $-79 \%$ \\
\hline 0301 - fish live & 1.70 & 1.97 & 0.27 & $16 \%$ & 0.10 & 0.07 & -0.03 & $-28 \%$ \\
\hline 0302 - fish fresh or chilled & 35.80 & 0.04 & -35.76 & $-100 \%$ & 5.50 & 0.00 & -5.50 & $-100 \%$ \\
\hline 0303 - fish frozen & 129.70 & 19.16 & -110.54 & $-85 \%$ & 99.90 & 14.03 & -85.87 & $-86 \%$ \\
\hline 0304 - fish fillets \& other fish meat & 6.80 & 4.96 & -1.84 & $-27 \%$ & 1.70 & 2.28 & 0.58 & $34 \%$ \\
\hline 0305 - fish dried salted etc, smoked etc, & 1.20 & 0.01 & -1.19 & $-99 \%$ & 0.10 & 0.00 & -0.10 & $-100 \%$ \\
\hline 0306 - crustaceans live fresh etc, and cooked & 29.80 & 37.66 & 7.86 & $26 \%$ & 6.30 & 7.30 & 1.00 & $16 \%$ \\
\hline 0307 - molluscs \& aquatic invertebrates & 11.00 & 0.10 & -10.90 & $-99 \%$ & 1.10 & 0.01 & -1.09 & $-100 \%$ \\
\hline
\end{tabular}

Source: Comtrade database Federal Customs Service of Russia (2017).

Dairy product exports from the countries of the European Union to Russia

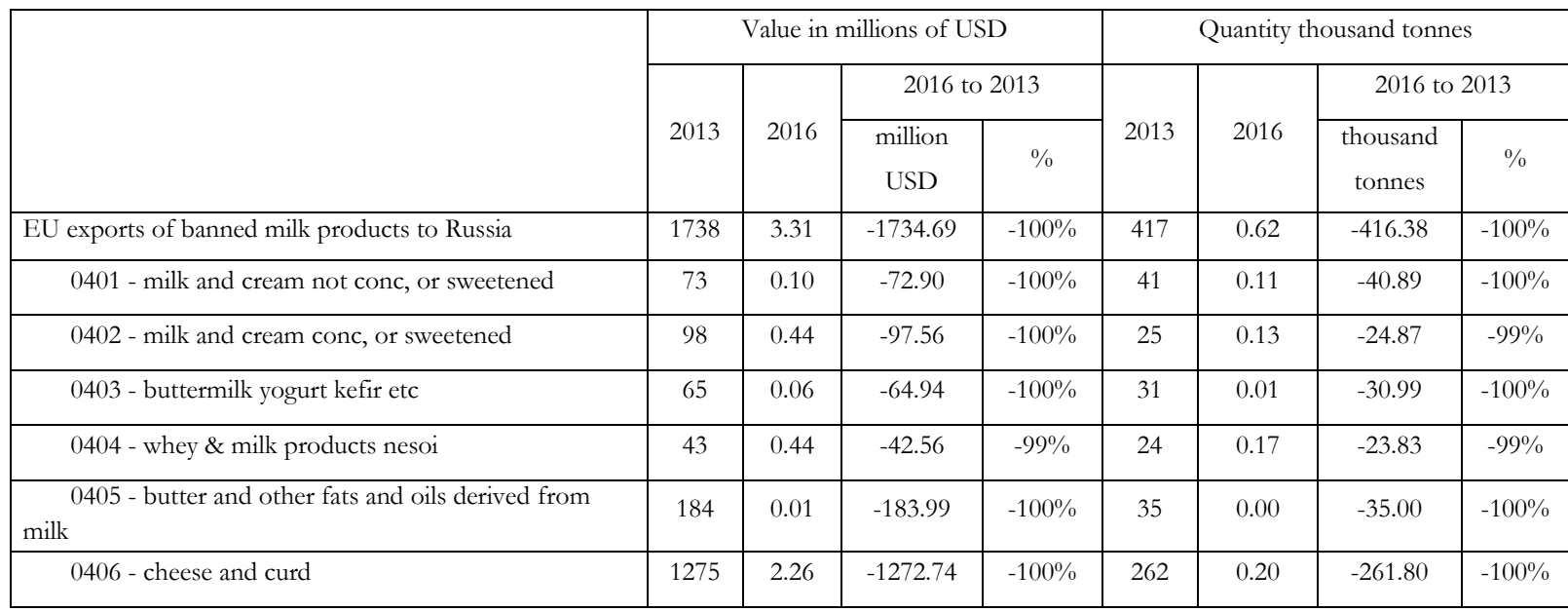

Source: Federal Customs Service of Russia (2017) 
Table A6

Test Changes in EU LFI index value performance in relation to Russia

\begin{tabular}{|c|c|c|c|}
\hline Commodity group & LFI 2013 & LFI 2016 & Changes 2013/2016 \\
\hline 0303 - fish, frozen & 12.3800 & 10.5966 & -1.7834 \\
\hline 0306 - crustaceans, live, fresh etc., and cooked & 1.8700 & 7.9125 & 6.0425 \\
\hline 0304 - fish fillets \& other fish meat & 1.4700 & 3.4868 & 2.0168 \\
\hline 0713 - leguminous vegetables, dried shelled & 1.1500 & 3.1539 & 2.0039 \\
\hline 0307 - molluscs \& aquatic invertebrates & 0.0600 & 0.7198 & 0.6598 \\
\hline 0401 - milk and cream, not conc. or sweetened & 0.1300 & 0.5233 & 0.3933 \\
\hline 0305 - fish, dried, salted etc., smoked etc. & 0.1500 & 0.4666 & 0.3166 \\
\hline 0802 - nuts nesoi & -0.2900 & 0.2014 & 0.4914 \\
\hline 0709 - vegetables nesoi & -0.2800 & 0.1699 & 0.4499 \\
\hline 1601 - sausages, similar prdt meat & 0.4400 & 0.1066 & -0.3334 \\
\hline 0403 - buttermilk, yogurt, kefir etc. & 0.5900 & 0.0930 & -0.4970 \\
\hline 0710 - vegetables (raw or cooked by steam) & -0.0800 & 0.0425 & 0.1225 \\
\hline 0711 - vegetables, temporarily preserved & 0.0200 & 0.0139 & -0.0061 \\
\hline 0807 - melons and papayas & -0.0100 & 0.0127 & 0.0227 \\
\hline 0801 - coconuts, brazil nuts \& cashew nuts & -0.0900 & 0.0000 & 0.0900 \\
\hline 0812 - fruit \& nuts temporarily preserved & 0.0000 & 0.0000 & 0.0000 \\
\hline 0708 - leguminous vegetables, fr or chill & 0.0200 & -0.0020 & -0.0220 \\
\hline 0210 - meat \& ed offal salted, dried & 0.0000 & -0.0031 & -0.0031 \\
\hline 0301 - fish, live & -0.0100 & -0.0226 & -0.0126 \\
\hline 0705 - lettuce and chicory & -0.0500 & -0.0439 & 0.0061 \\
\hline 0811 - fruit \& nuts (raw or cooked by steam) & 0.1200 & -0.0592 & -0.1792 \\
\hline 0704 - cabbages, cauliflower, kale & -0.1300 & -0.0992 & 0.0308 \\
\hline 0302 - fish, fresh or chilled & -0.9900 & -0.1202 & 0.8698 \\
\hline 0813 - fruit dried nesoi & -0.1100 & -0.1405 & -0.0305 \\
\hline 0712 - vegetables, dried, whole, cut & -0.0300 & -0.1822 & -0.1522 \\
\hline 0701 - potatoes & -0.1700 & -0.2166 & -0.0466 \\
\hline 0404 - whey \& milk products nesoi, & -0.0900 & -0.2193 & -0.1293 \\
\hline 0707 - cucumbers and gherkins & -0.3000 & -0.2484 & 0.0516 \\
\hline 0804 - dates, figs, pineapples, avocados & -0.1500 & -0.2963 & -0.1463 \\
\hline 0706 - carrots, turnips \& other edible roots & -0.1900 & -0.3064 & -0.1164 \\
\hline 0703 - onions, shallots, garlic, leeks & -0.2100 & -0.4200 & -0.2100 \\
\hline 0401 - milk and cream, not conc. or sweetened & -0.1200 & -0.5120 & -0.3920 \\
\hline 0806 - grapes & -0.5800 & -0.5735 & 0.0065 \\
\hline 2106- fruit dried & -0.0800 & -0.6412 & -0.5612 \\
\hline 0810 - fruit nesoi & -0.6100 & -0.6872 & -0.0772 \\
\hline 1901 - fruit dried nesoi & -0.0400 & -0.7221 & -0.6821 \\
\hline 0809 - apricots, cherries, peaches, plums & -0.6400 & -0.7234 & -0.0834 \\
\hline 0207 - meat \& ed offal of poultry & -0.4700 & -0.8537 & -0.3837 \\
\hline 0201 - meat of bovine animals, fresh or chilled & -0.4300 & -1.1800 & -0.7500 \\
\hline $0702-$ tomatoes & -1.1400 & -1.2991 & -0.1591 \\
\hline 0405 - butter and other milk fats and oils & -0.6500 & -1.5679 & -0.9179 \\
\hline 0402 - milk and cream, conc. or sweetened & -0.4200 & -1.7817 & -1.3617 \\
\hline 0808 - apples, pears and quinces & -1.2100 & -1.8515 & -0.6415 \\
\hline 0203 - meat of swine (pork) & -2.1900 & -1.8548 & 0.3352 \\
\hline 0803 - Bananas and plantains & -0.8000 & -1.9527 & -1.1527 \\
\hline 0406 - cheese and curd & -1.6700 & -2.5220 & -0.8520 \\
\hline 0202 - meat of bovine animals, frozen & -2.4800 & -3.1538 & -0.6738 \\
\hline 0805 - citrus fruit & -1.7000 & -3.2429 & -1.5429 \\
\hline
\end{tabular}

Source: Comtrade database and own processing (2017) 